\title{
Communication effectiveness in social networks of leading universitie
}

Efectividad de la comunicación en redes sociales de universidades lideres

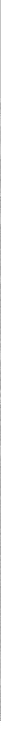

\section{Abstract}

The article presents the results of communication effectiveness analysis in social networks of leading universities with strong economic departments. The study was carried out using the textual information analysis i.e. content, links, posts, comments, tags, etc.; multimedia i.e. photos, videos, audio, etc., and the ontology method, which estimated the social networks parameters like the number of subscribers, average path length, etc.

The study showed that the main platform for international higher education institutions is Facebook; Instagram is actively developing, and then comes YouTube. The number of publications does not directly affect the number of subscribers, in contrast to the number of students. The high frequency of posts does not lead to subscribers increase. There is no single strategy for universities social network development. The use of informal communication, which encourages action, significantly increases the audience and its involvement; but is not used by all universities, because it might contradict with the university's image. It should be noted that good design, the use of professional photos and videos, has its impact on potential audience. 


\section{Resumen}

El artículo presenta los resultados del análisis de la efectividad de la comunicación en las redes sociales en las principales universidades con departamentos económicos sólidos. El estudio se Ilevó a cabo utilizando el análisis de información textual, es decir, contenido, enlaces, publicaciones, comentarios, etiquetas, etc .; multimedia, es decir, fotos, videos, audio, etc., y el método ontológico, que estimó los parámetros de las redes sociales como el número de suscriptores, la longitud promedio de la ruta, etc.

El estudio mostró que la principal plataforma para las instituciones internacionales de educación superior es Facebook; Instagram se está desarrollando activamente y luego viene YouTube. El número de publicaciones no afecta directamente al número de suscriptores, a diferencia del número de estudiantes. La alta frecuencia de publicaciones no conduce a un aumento de suscriptores. No existe una estrategia única para el desarrollo de redes sociales de las universidades. El uso de la comunicación informal, que fomenta la acción, aumenta significativamente la audiencia y su participación; pero no es utilizado por todas las universidades, porque podría resultar contrario a la imagen de la universidad. Cabe señalar que un buen diseño, el uso de fotos y videos profesionales, tiene su impacto en la audiencia potencial.

\section{Keywords}

SMM of economic universities, content, social networks, social networks structure, structure of communications.

\section{Palabras clave}

SMM de facultades de Económía, contenidos, redes sociales, estructura de redes sociales, estructura de comunicaciones.

\section{Summary}

1. Introduction

2. Study purpose

3. Literature Review

4. Methods

5. Results.

6. Discussion

7. Conclusion

8. Bibliography

\section{Sumario}

1. Introducción

2. Propuesta de estudio

3. Revisión bibliográfica

4. Metodología

5. Resultados

6. Discusión

7. Conclusión

8. Bibliografía 


\section{Introduction}

Building communications through social networks is becoming one of the most significant areas of information activity. Since young people get the bulk of information through social networks, it is highly relevant for universities to keep their own accounts on social networks. In addition, this activity requires universities to allocate some resources.

Since university communications in social media began to develop not so long ago, leading universities opened the first public only around 10 or 12 years ago; however, they have not been studied enoughso far. In this regard, the theoretical base is not sufficiently developed and presented fragmentarily, mainly by articles that rely on theories that exist at the intersection of sciences related to the issues of communication management, management of higher educational institutions, integrated communications used in the promotion of educational services, and theory directly related to social networks, their evolution, structure, methods of analysis, functioning.

\section{Study purpose}

To identify the influence of social networkcommunication on leading universities with strong economic departments and effectiveness of this communication. The interdependence of textual information i.e. types of content, links, posts, comments, tags, etc.; multimedia i.e. photos, videos, audio, etc. (Batura, 2013) and the ontology method analysisresults, which estimated the social networkparameters i.e. number of subscribers, average path length, etc.(Érétéo et al, 2009).

In this case, the communication effect is evaluated by the behavioral characteristics of the recipient in corresponding social networks. These aresubscribing, giving thumbs up, writing comments and reposting messages.

One of the main tasks is also to find out which of the social networks is the main for international higher education institutions. The most common networks such as Facebook, Instagram and Youtube are considered. The number of subscribers, the publication frequency and the number of students is determined. Moreover, the influence of communication style, usage of professional photos and videos on social networks is examined. It should be noted that the concept of a unified strategy of social networks for universities must be worked out.

As a result of the study, a conclusion should be made about further studying of the social networks communication effectiveness of leading universities. 


\section{Literature Review}

At the end of the $19^{\text {th }}$ and beginning of the $20^{\text {th }}$ centuries, people began studying the issues of social relations in groups of people. Emil Durkheim argued that not all social phenomena could be explained in terms of individual features. Georg Simmel studied poorly connected social structures, he might have laid the foundations of social networks analysis. Social philosophers of that time used the 'web of relationships'term. (Simmel, 1996).

The study of social networks became practical in the first half of the 20th century, when the United States began to use sociograms, where individuals were represented as 'points', and the lines between them reflected the relationship. For the first time this method was applied by Moreno (Moreno, 2001). The keypersons were Harrison White (White, 2008), Barry Wellman (Wellman\&Berkowitz, 1998) Linton Freeman (Freeman, 2004).

Social networks are a complex phenomenon and is not easily defined. Gradoselskaya G.V. proposes to use a sequence of definitions in which a network is characterized as a special type of relationship between the positions of individuals, selected in accordance with the purpose of building a network. The location of individuals is called 'the network nodes'. Connections between them create a network structure. Some connections may be absent or even stronger than the others may. (Gradoselskaya, 2004).

Darrell West believed that social networks are like a special subculture, and the space for the formation of social capital is a platform that accumulates social knowledge (West, 2012).

A relatively new concept is 'virtual social networks'. Boyd D.M. and Alison N.B.defined virtual social networks as a web-based service that allows individual users (Boyd\&Ellison, 2008) to create open or partially open profiles, i.e. characteristics describing the user's identity, for example gender, age, education, geographical location, etc.; see a list of their communications, i.e. users with whom they interact within the system and friends; get the access to thefriends' communications, i.e. to social networks of other users within the system.

The emotional influence of social networks and brand attachment in the educational segment have not been studied yet, but such kind of research is being carried out for other areas. Studies conducted by Hudson S. showed that social networks have a significant impact on emotions and affection for festival brands and give the desired result, i.e. the word of mouth (Hudson, Roth, Madden 2015).

Social networks can also be a management model in which the possibility of structural feedback plays an important role (Baptista et al., 2017). Different strategies 
for managing social networks affect the difference in their social perceptions (Benthaus \&Risius, 2016). As a result, it is possible to consciously manipulate the system, i.e. to either increase your own social capital or reduce the cost of others (Karoui et al., 2015). At the same time, it is important to manage two different types of communications,i.e. content created by the organization and user-generated one, which can give rise to ambiguity in communication (Huang et al., 2015).

The discovery of communities is a key research tool for applications in various fields, i.e. searching for communities on social and biological networks. The problem of finding communities or clusters in the network has received great attention from statistics, physics and computer science. (Bickel PJ, Sarkar P, 2016). The socio-demographic characteristics of social networks participantscan form the structural 'nodes' of network. (Newman\& Clauset, 2016).Markov models that allow communities to be detected even for temporary networks describe the network nodes. (Salnikov et al., 2016). There are two definitions for network communities, i.e. the structural ones and the functional ones. The structural definitions are based on connectivity models, such as link density between community members, while the functional definitions are based on the overall function or role of community members in a network. (Yang\& Leskovec, 2015). Not one algorithm can solve the community discovery problem. (Peel et al., 2016; Newman, 2016).

Social networks can influence the loyalty of company employees and increase the sense of community within the company (Hutter et al., 2017).

The development of the Internet and information technology makes it possible to promote educational services,attract individuals and create the image of educational organizations.(Tarasova\&Shein, 2014).

To promote educational services, the economic literature proposes the following principles, i.e.individual needs consideration, target audience communication, unobtrusive advertising, quality prioritizing, creative and professional approach.(Tarasova\&Shein, 2017).

Social networks features allow you to identify users who are interested in information about the university, and send ads to specific users, depending on their profile content.

Many scientists have dealt with issues related to the management of university communications. Rubin O.B. he concentrated his attention on studying the promotion of entrepreneurial universities (Rubin, 2005). Selyutin A.A. considered the corporate culture of the university as a combination of texts, i.e. the linguo-cultural analysis.

Makarets A.B. highlighted the methodology for quality assessing and university websites and portals effectiveness. (Makarets, 2009). Shpolyanskaya I.Y. and Vorobyova A.M. considered models and methods for optimizing the structure of universities educational 
portals in the Internet marketing system. (Shpolyanskaya, 2012). Gureeva A.N. considers social networks as a media and communication resource for managing the Russian university image. (Gureeva, 2015).

Educational networks are considered in terms of their composition and access to educational content. (Van Waes et al., 2018). The role of social networks in combining formal and non-formal learning through a collaborative digital culture is also high. (Christine Greenhow \& Cathy Lewin, 2016). The use of social networks provides numerous benefits for learning and teaching, such as increased teacher-student and student-student interaction, increased productivity, easier learning, and higher engagement. (Chugh, R., \& Ruhi, U., 2018). In addition, the use of social networks in the learning process contributes to the development of self-education and critical thinking skills (Habibi et al., 2018).

University social networksissues are discussed in the articlenamed 'University Social Networks Content ' ('University Social Networks Content ', 2018). It highlights the most popular networks for 2018 in the CIS countries. These are Facebook, Vkontakte, YouTube and Instagram. A number of recommendations are given on the photo and video, texts, stories, live broadcasts. The most popular topics for universities such as events, interviews, educational content and the success of university students are considered.

The above facts show that the issues related to the promotion of universities are relevant, and the communications carried out by universities through social networks are multifaceted and require detailed study, but there are very few works devoted to studies of the communication effectiveness in social networks of universities or they are devoted to a narrow range of problems. This allows us to conclude that research in this area is relevant and has a high potential.

\section{Methods}

The study was conducted based onfive-world universities social networks analysis. The selection of universities was carried out based on the universities ranking in the world, i.e. QS (QS Global World Ranking) 2018 (QS Global World Ranking, 2018). Universities with strong economic departmentswere selected, with a rough equal number of students, but in significantly different ranking positions. The list of universities indicates the first number as the rating, and the second - is the number of students, i.e. ColumbiaUniversity $(16,26160)$, The London School of Economics and Political Science $(38,10357)$, Oxford Brookes University $(363,15274)$, University of Limerick 
(511, 12005), The University of Phoenix (- / 142500). The last university is not included in the rating, but has well-developed social networks; this is largely due to the fact that it goes first in the universities ranking, proudly obtaining the online MBA programs and it is one of the youngest universities.

The study result should highlight the most successful universities public profiles (by subscribers' number, likes, comments, message reposts and adding to favorites). The main characteristics should beconsidered and evaluated, the advantages should be identified and the reasons or conditions promoting the universities social networks development ought to be clarified.

Apart from some traditional research methods, such as complex analysis method, material processing method, information generalizationmethod, effectiveness assessing methods and qualitative and quantitative ones, the specific methods wereused to analyze social networks, i.e. textual information analysis (types of content, links, posts, comments, tags, etc.), multimedia (photo, video, audio, etc.) [13] and the ontology method, which estimates the social networks parameters (subscribers' number, average path length, etc.) (Érétéo et al, 2009).

Universities activitieson Facebook, Instagram, YouTube and Twitter are considered. Key analysis parameters are the number of subscribers, engagement, net increase, percentage of 'bots, dead accounts, inactive accounts', percentage of target audience in the community, active core, discussions, subscribers coverage, negative feedback, response frequency and the number of discussions.

The correlations of educational, entertaining, branded and informational content are investigated. The frequency of posts, the highest user time activity, vivid content and the text and image proportion are also analyzed. The types of content are sorted, such as lists, cases, studies, frequently asked questions, checklists, action manuals, definitions, series of posts, statistics, biography, gathering opinions, interviews, people - examples, irony, animation, memes, parody, review, survey, news, trend, problem solving, congratulations, revelations, behind the scenes, hot topics, comparison, project showcase, income report, company news and etc. The analysis also uses the indicators proposed by Tarasova $\mathrm{E}$. and Shein E.A. for educational portals evaluation, such as functional, informational and related to user convenience.

The article defines the structure of universities social networks in terms of the indicators mentioned earlier. In addition, the specifics of world's leading universities communication activity in social media were shown. And effectiveness increase recommendations are offered as well. 


\section{Results}

It is important to characterize the universities, whose social networks are being studied, in order toevaluate the study results.

University of Limerick is the largest Irish university located in the ancient city of Limerick in western Ireland. It was founded in 1972. It received its university status in 1989. The university owes much to such a rapid development to philanthropist Charles Finn, who invested more than $\$ 170$ million in it. Currently, the university has gained an excellent reputation and is listed in the top ten developing universities. It also entered the top 500 world universities according to the ranking held by QS World University Rankings in 2011. Ranked 52nd in the overall ranking of universities in the UK and Ireland according to QS World University Rankings in 2007. Currently, the university has about 12,000 students studying in four departments, i.e. Kemmy Business School; Faculty of Education and Health Sciences (Faculty of Education \& Health Sciences); Faculty of Science and Technology (Faculty of Science \& Engineering); Faculty of Arts, Humanities and Social Sciences (Faculty of Arts, Humanities \& Social Sciences).

Oxford Brookes University (OBU) is a public higher education institution in the UK. The history of OBU dates back to 1865 . The university regularly takes top places in the ranking of the best universities in the UK. Oxford Brookes University is traditionally in the top $5 \%$ of world educational rankings. This educational institution is in the top 400 of higher educationquality. Has a high reputation among employers around the world. Holds more than 14 thousand students. The university is a member of several groups and associations, including the Association of Commonwealth Universities (ACU), as well as Universities UK and the University Alliance. Oxford Brooks is strong in areas such as architecture, automotive and auto-sports technology, healthcare, history, hospitality, publishing, management and business. The University has major research projects that are constantly sponsored.

Columbia University, the official name Columbia University of New York is a private research university in New York (informally known as just 'Columbia'), is one of the most famous and prestigious universities in the United States. It is a part of the elite Ivy League. It is the association of eight private American universities, the name comes from ivy shoots encircling old buildings in these universities. It is believed that members of the league are of high educationquality. The motto of the university is 'In the light of yours we shall see the light' (Latin 'In lumine tuo videbimus lumen').

Columbia University is the oldest institution of higher education in New York State, and it is the fifth in the list of oldest universities in the United States. Colombia is 
second only to Harvard in the number of Nobel laureates. The educational institution was founded in 1754 as Kings College. The university is located in the Manhattan area, where it occupies 6 quarters (or 13 hectares). There you can study almost any well-known discipline, from journalism and the arts to nursing and dentistry, as well as gain valuable practical and research experience. Around 30 thousand students study at the university every year. The quality of education at Columbia University is mentioned at the international level. The university ranks $16^{\text {th }}$ among the best universities in the world by QS World University Rankings 2018. In addition, Columbia University regularly holds top positions in many national and world ratings (Columbia University, 2018).

The University of Phoenix, which has proclaimed itself the largest private university in North America, has an annual turnover of $\$ 4$ billion and offers programs in the United States and Europe. The scale of the largest commercial university is proved by the fact that the turnover of educational services at the University of Phoenix is almost double the budget of the University of Virginia [24]. It was founded in 1976 in the city of Phoenix, Arizona. It includes over 200 campuses. One of the main areas is a distance MBA education. About 300,000 students study at the university. The university offers associate, bachelor and master degrees in accounting, e-commerce, marketing, management, information technology and nursing. In addition, doctoral programs in the fields of arts and sciences, business and management, criminal justice and security, pedagogy, public services, nursing and health care, psychology and technology are available to students.

The London School of Economics and Political Science (LSE) is a public research university located in the heart of London, near the Thames. The leaders of the Fabian Society, a socialist philosophical movement that ideologically contrasts itself with conservatives, founded the London School of Economics in 1895. In other words, the LSE is, first, a 'left-wing' and anti-imperial institution, which at the same time is a leading center for the study of political and social issues. The London School of Economics is part of the University of London and is part of the Golden Triangle along with Oxford and Cambridge Universities.

The London School of Economics and Political Science is the best university for financial experts and political science profile of public administration. Leading professors from several rating universities teach there. Lectures on political science, public administration for students are given by leaders of many countries. In the conference rooms of the London school, people like Bill Clinton, David Cameron, Angela Merkel, Tony Blair, Dmitry Medvedev, Nelson Mandela and others gave their speech. 
The London School of Economics and Political Science today brings together 9,000 students. The contingent is represented by citizens of 140 countries. The teaching staff is also multinational. The school employs educators from 45 countries.

The Library of the London School of Economics is the largest library in the world by the number of books on the social sciences and contains literature in all major European languages.

The main research areas that are cultivated in the school.

LSE research centers have released more than a dozen of Nobel Prize winners, among whom there are five who have received an award in the field of economics. They are John Mead, John Hicks, Alfred von Hayek, Arthur Lewis and Ronald Coase.

The universities, under study, had created communities on Facebook quite a long time ago (see Table 1). The London School of Economics and Political Science opened the very first community in 2017.

\section{TABLE 1}

\section{Dates of university community creation on Facebook}

\begin{tabular}{|c|c|c|}
\hline University & Community Address on fb.com & Community Creation Date \\
\hline University of Limerick & https://www.facebook.com/universityoflimerick & 29.11.2010 \\
\hline $\begin{array}{l}\text { Oxford Brookes } \\
\text { University }\end{array}$ & https://www.facebook.com/oxfordbrookes/ & 6.7 .2009 \\
\hline $\begin{array}{l}\text { Columbia University in } \\
\text { the City of New York }\end{array}$ & https://www.facebook.com/columbia/ & 10.6.2009 \\
\hline $\begin{array}{l}\text { The University of } \\
\text { Phoenix / USA }\end{array}$ & https://www.facebook.com/universityofphoenix/ & 21.7.2008 \\
\hline $\begin{array}{l}\text { The London School } \\
\text { of Economics and } \\
\text { Political Science }\end{array}$ & https://www.facebook.com/lseps/ & 12.11.2007 \\
\hline
\end{tabular}

On November 7, 2018, according to the data of the statistics and analytics service of the social communities content of Popsters, the University of Phoenix has the largest number of subscribers (see table 2). (Engagementrate: how to calculate the engagement rate on social networks, 2018). 
TABLE 2

University Community Facebook Statistics

\begin{tabular}{|c|c|c|c|c|c|}
\hline Name & $\begin{array}{l}\text { University } \\
\text { of Limerick }\end{array}$ & $\begin{array}{l}\text { Oxford } \\
\text { Brookes } \\
\text { University }\end{array}$ & $\begin{array}{c}\text { Columbia } \\
\text { University in the } \\
\text { City of New York }\end{array}$ & $\begin{array}{l}\text { University of } \\
\text { Phoenix }\end{array}$ & $\begin{array}{l}\text { The London School of } \\
\text { Economics and Political } \\
\text { Science - LSE }\end{array}$ \\
\hline Subscribers & 54177 & 144700 & 372634 & 1847550 & 425805 \\
\hline $\begin{array}{c}\text { Total } \\
\text { publications }\end{array}$ & 2397 & 3395 & 4506 & 2907 & 4716 \\
\hline Likes & 214631 & 136323 & 576085 & 4684256 & 466456 \\
\hline Share & 27336 & 9171 & 85498 & 386491 & 50634 \\
\hline Comments & 11832 & 7425 & 20920 & 216321 & 15318 \\
\hline ER Day & 0.156 & 0.003 & 0.005 & 0.019 & 0.042 \\
\hline ER Post & 0.195 & 0.031 & 0.041 & 0.098 & 0.027 \\
\hline ER View & 0.000 & 0.000 & 0.000 & 0.000 & 0.000 \\
\hline LR & 0.165 & 0.028 & 0.034 & 0.087 & 0.023 \\
\hline TR & 0.009 & 0.002 & 0.001 & 0.004 & 0.001 \\
\hline Likes & 90 & 40 & 128 & 1611 & 99 \\
\hline Reposts & 11 & 3 & 19 & 133 & 11 \\
\hline Comments & 5 & 2 & 5 & 74 & 3 \\
\hline
\end{tabular}

Table 2 shows that the University of Phoenix has the largest number of subscribers, likes, reposts and comments, while the number of posts in its community is one of the smallest, which can indicate more attractive content for subscribers and visitors, and we can also make an assumption about a wider network of representative offices in the world, and, accordingly, a larger number of students, applicants, graduates and employers. 


\section{TABLE 3 \\ Instagram Universities Communities}

\begin{tabular}{|c|c|}
\hline University & Instagram Community Address \\
\hline University of Limerick & https://www.instagram.com/universityoflimerick/ \\
\hline Oxford Brookes University & https://www.instagram.com/oxfordbrookes/ \\
\hline Columbia University in the City of New York & https://www.instagram.com/columbia/ \\
\hline The University of Phoenix / USA & https://www.instagram.com/uopx/ \\
\hline $\begin{array}{c}\text { The London School of Economics and } \\
\text { Political Science }\end{array}$ & https://www.instagram.com/londonschoolofeconomics/ \\
\hline
\end{tabular}

TABLE 4

\section{Instagram University Community Statistics}

\begin{tabular}{c|c|c|c|c|c} 
Name & $\begin{array}{c}\text { University } \\
\text { of Limerick }\end{array}$ & $\begin{array}{c}\text { Oxford Brookes } \\
\text { University }\end{array}$ & $\begin{array}{c}\text { Columbia } \\
\text { University }\end{array}$ & $\begin{array}{c}\text { University of } \\
\text { Phoenix }\end{array}$ & $\begin{array}{c}\text { The London School of } \\
\text { Economics }\end{array}$ \\
\hline
\end{tabular}

\begin{tabular}{|c|c|c|c|c|c|}
\hline Subscribers & 13945 & 8265 & 160097 & 10813 & 82610 \\
\hline $\begin{array}{c}\text { Total } \\
\text { publications }\end{array}$ & 612 & 412 & 1177 & 547 & 2011 \\
\hline Likes & 179783 & 72081 & 3007240 & 205295 & 953615 \\
\hline Comments & 2693 & 641 & 20668 & 2198 & 8044 \\
\hline ER Day & 0.934 & 0.703 & 0.990 & 0.943 & 0.870 \\
\hline ER Post & 2.138 & 2.136 & 1.607 & 3.508 & 0.579 \\
\hline ER View & 0.000 & 0.000 & 0.000 & 0.000 & 0.000 \\
\hline LR & 2.107 & 2.117 & 1.596 & 3.471 & 0.574 \\
\hline TR & 0.032 & 0.019 & 0.011 & 0.037 & 0.005 \\
\hline Likes & 294 & 175 & 2555 & 375 & 474 \\
\hline Comments & 4 & 2 & 18 & 4 & 4 \\
\hline
\end{tabular}

Columbia University and London School of Economics have the most successful audience engagement on Instagram.However, Columbia University's audience engagement is nearly 4 times higher than the London School of Economics. In the future, a more detailed study of the content and creative component of the posts is required in order to identify the cause of high engagement. 
TABLE 5

Youtube University Communities

\begin{tabular}{|c|c|}
\hline University & Instagram Community Address \\
\hline University of Limerick & https://www.youtube.com/channel/UCUW1fIRLyvCeZ4e6TefB1xQ \\
\hline Oxford Brookes University & https://www.youtube.com/channel/UC7bqbmApisrJUGleJwuF8mw \\
\hline $\begin{array}{c}\text { Columbia University in the City } \\
\text { of New York }\end{array}$ & https://www.youtube.com/channel/UChzhFUxUZFAQSIZ_Tp4B1fA \\
\hline The University of Phoenix / USA & https://www.youtube.com/channel/UCDF_b201L_z9YG8_PnCv0yg \\
\hline $\begin{array}{l}\text { The London School of } \\
\text { Economics and Political Science }\end{array}$ & https://www.youtube.com/channel/UCK08_B5SZwoEUk2hDPM0ijQ \\
\hline
\end{tabular}

TABLE 6

University community statistics on Youtube

\begin{tabular}{|c|c|c|c|c|c|}
\hline Name & $\begin{array}{l}\text { University } \\
\text { of Limerick }\end{array}$ & $\begin{array}{l}\text { Oxford Brookes } \\
\text { University }\end{array}$ & $\begin{array}{l}\text { Columbia } \\
\text { University }\end{array}$ & $\begin{array}{l}\text { University of } \\
\text { Phoenix }\end{array}$ & $\begin{array}{c}\text { The London School of } \\
\text { Economics }\end{array}$ \\
\hline Subscribers & 3275 & 6447 & 54047 & 20019 & 119912 \\
\hline $\begin{array}{c}\text { Total } \\
\text { publications }\end{array}$ & 725 & 576 & 1606 & 47 & 2616 \\
\hline Likes & 4233 & 5665 & 35469 & 15258 & 70564 \\
\hline Comments & 288 & 709 & 6545 & 3938 & 12212 \\
\hline Dislikes & 338 & 275 & 3064 & 2770 & 5509 \\
\hline Views & 1371869 & 1777853 & 8974316 & 43942743 & 10838126 \\
\hline ER Day & 0.046 & 0.032 & 0.024 & 0.112 & 0.024 \\
\hline ER Post & 0.205 & 0.179 & 0.052 & 2.335 & 0.028 \\
\hline ER View & 0.566 & 0.586 & 0.595 & 1.134 & 0.877 \\
\hline LR & 0.178 & 0.153 & 0.041 & 1.622 & 0.022 \\
\hline TR & 0.012 & 0.019 & 0.008 & 0.419 & 0.004 \\
\hline Likes & 6 & 10 & 22 & 325 & 27 \\
\hline Comments & 0,4 & 1 & 4 & 84 & 5 \\
\hline
\end{tabular}


The London School of Economics is most active on YouTube, while Columbia holds the second place in terms of subscribers number and posts, but the content of the University of Phoenix should be further analyzed, as with a small number of posts, the highest involvement was achieved, exceeding the leader by almost 16 times.

The social networks audienceanalysis of the universities presented above showed that visitors aged 25 to 44 years are dominant. They are applicants, students and graduates.

\section{TABLE 7}

\section{Time indicators}

\begin{tabular}{|c|c|c|c|c|c|}
\hline Content type & $\begin{array}{l}\text { University } \\
\text { of Limerick }\end{array}$ & $\begin{array}{l}\text { Oxford Brookes } \\
\text { University }\end{array}$ & $\begin{array}{l}\text { Columbia } \\
\text { University }\end{array}$ & $\begin{array}{l}\text { University of } \\
\text { Phoenix }\end{array}$ & $\begin{array}{c}\text { The London School of } \\
\text { Economics }\end{array}$ \\
\hline $\begin{array}{c}\text { Post } \\
\text { frequency }\end{array}$ & $\begin{array}{l}\text { Once in } 3 \\
\text { or } 4 \text { days }\end{array}$ & Once a day & Once a day & $\begin{array}{c}\text { Once in } 2 \text { or } 3 \\
\text { days }\end{array}$ & $\begin{array}{c}\text { From } 2 \text { to } 8 \text { posts } \\
\text { daily }\end{array}$ \\
\hline $\begin{array}{l}\text { Highest user } \\
\text { activity time }\end{array}$ & $\begin{array}{l}\text { 9a.m. } \\
\text { and8 p.m., } \\
\text { Sunday }\end{array}$ & $\begin{array}{l}7 \text { a.m. } \\
\text { Tuesday and } \\
\text { Sunday }\end{array}$ & $\begin{array}{l}3 \text { p.m. } \\
\text { Sunday }\end{array}$ & $\begin{array}{l}12 \text { p.m. and } \\
4 \text { p.m. } \\
\text { Monday and } \\
\text { Sunday }\end{array}$ & $\begin{array}{l}\text { From } 12 \text { p.m. to } 4 \text { p.m. } \\
\text { Tuesday, } \\
\text { ThursdayandSunday }\end{array}$ \\
\hline $\begin{array}{l}\text { Text / Image } \\
\text { Ratio }\end{array}$ & $1 / 1$ & $1 / 3$ & $1 / 3$ & $1 / 3$ & $2 / 3$ \\
\hline
\end{tabular}

Table 7 shows that all universities social networks are actively visited on a Sunday. However, it is impossible to identify the general trend of the best posting time. The London School of Economics (up to eight posts a day) carries out the most intensive work on the posts publication, and they observe the users' highest activity time depending onthe posting time.

\section{TABLE 8}

The proportion of educational, entertainment, branded and information content

\begin{tabular}{|c|c|c|c|c|c|}
\hline Content type & $\begin{array}{c}\text { University } \\
\text { of Limerick }\end{array}$ & $\begin{array}{c}\text { Oxford Brookes } \\
\text { University }\end{array}$ & $\begin{array}{c}\text { Columbia } \\
\text { University }\end{array}$ & $\begin{array}{c}\text { University of } \\
\text { Phoenix }\end{array}$ & $\begin{array}{c}\text { The London School of } \\
\text { Economics }\end{array}$ \\
\hline Educational & $15 \%$ & $10 \%$ & $10 \%$ & $5 \%$ & $20 \%$ \\
\hline Entertaining & $15 \%$ & $20 \%$ & $30 \%$ & $50 \%$ & $5 \%$ \\
\hline Branded & $20 \%$ & $10 \%$ & $20 \%$ & $35 \%$ & $5 \%$ \\
\hline Informational & $50 \%$ & $60 \%$ & $40 \%$ & $10 \%$ & $70 \%$ \\
\hline
\end{tabular}


Universities social networks are used to convey information publicly (see table 8). The share of information content ranges from $40 \%$ for Columbia and up to $70 \%$ for LondonSchoolofEconomics. The exception is the University of Phoenix, its specificity implies a small amount of information content just 10\%; the entertainment content is $50 \%$ and the branded one is $35 \%$. In all the studied networks, the educational content represented quite modestly, from $5 \%$ for the University of Phoenix to $20 \%$ for the London School of Economics.

\section{TABLE 9}

\section{The content topics proportion}

\begin{tabular}{|c|c|c|c|c|c|}
\hline Type of content & $\begin{array}{c}\text { University of } \\
\text { Limerick }\end{array}$ & $\begin{array}{l}\text { Oxford Brookes } \\
\text { University }\end{array}$ & $\begin{array}{l}\text { Columbia } \\
\text { University }\end{array}$ & $\begin{array}{l}\text { University of } \\
\text { Phoenix }\end{array}$ & $\begin{array}{c}\text { The London School } \\
\text { of Economics }\end{array}$ \\
\hline List & & & + & + & \\
\hline Cases & & + & + & & + \\
\hline $\begin{array}{l}\text { Sports and cultural life } \\
\text { of students }\end{array}$ & & + & + & & + \\
\hline Research & + & + & + & & \\
\hline FAQ & & & & & \\
\hline Check-lists & & & & & \\
\hline Action guides & & + & + & + & \\
\hline Definitions & & & & & \\
\hline Series of posts & & & + & + & + \\
\hline Statistics & + & + & + & + & \\
\hline Biography & + & + & + & + & \\
\hline Collecting opinions & & & + & + & \\
\hline Interview & + & + & + & & + \\
\hline Interview with alumni & & + & + & + & + \\
\hline $\begin{array}{l}\text { Why did } \\
\text { studentschoose this } \\
\text { university }\end{array}$ & & + & & + & \\
\hline
\end{tabular}




\begin{tabular}{|c|c|c|c|c|c|}
\hline \multicolumn{6}{|l|}{ Main thing for the week } \\
\hline People-examples & + & + & + & + & + \\
\hline Irony & + & & + & + & \\
\hline Animation & & & + & + & \\
\hline Memes & & & + & + & \\
\hline Parody & & & + & + & \\
\hline Review & + & + & + & & \\
\hline Survey & & & + & + & \\
\hline $\begin{array}{c}\text { News and } \\
\text { announcements }\end{array}$ & + & + & + & & + \\
\hline \multicolumn{6}{|l|}{ Trend } \\
\hline Problem solving & & & & + & \\
\hline Congrats & + & + & + & + & \\
\hline Sponsors appreciation & & + & & & \\
\hline $\begin{array}{l}\text { Living conditions, new } \\
\text { premises opening or } \\
\text { repair works }\end{array}$ & & + & & & \\
\hline Revelations & & & & + & \\
\hline Behind the scenes & & & + & & \\
\hline Off records & & & + & + & \\
\hline Hot topics & & & + & & + \\
\hline Comparison & & & & & + \\
\hline $\begin{array}{l}\text { Student photos and } \\
\text { videos }\end{array}$ & + & + & + & + & \\
\hline Company news & + & + & + & + & + \\
\hline
\end{tabular}

Table 9 showsthat the question of posting a particular type of content is solved in different ways. For instance, University of Limerick limits its posts to standard news and 
announcements, nature photos made by students; it may give the statistics on the university's annual work, holidays or achievements congrats;there you can also findteachers'biography, interviews and some ironic posts as well.

Oxford Brookes University uses all of the above topics, but they also post acknowledgements to sponsors, information about the living conditions of students in dormitories, etc. In addition,you can find materials about 'How to ...' perform a particular task, cases presented, you can learn about the sports and cultural life of students, about their future career from their interviews, about the reasons of entering the university by current students.

Columbia University tends to depart from formal communication and most of the posts are filled with humor, irony, which makes them more attractive to the audience. Some animation is applied, as well as some memes. Closer communication with the audience is achieved by posting surveys, it is also proposed to discuss hot topics and look behind the scenes of the educational process.

The London School of Economics does not set its task a high audience involvement, but it rather conveys information about numerous events like open lectures in the university. It is quire expected to find some sort of comparisons with other universities in student's interviews.

The University of Phoenix is trying to smooth out the shortcomings of distance education by using social networks. Since the motivation of distance-learning students weakens due to the lack of full-time communication. Networks are considered as platforms for active motivating communication. Seeing this, most lightweight communication topics are used, which can energize the audience and involve it in communication by creating a sense of community. It uses humor, memes, skits, action guides, lists, revelations and personal success stories.

Network cover designs ought to be examined separately. University of Limerick is the only university that uses a static image. Oxford Brookes University has posted a video that creates a calm, measured autumn mood, most suitable for the elderly. Columbia University uses time-lapse video. A sense of dynamics is created; the best views of the University are given. Incentives and motivation are key to the University of Phoenix, i.e. a large, bright slogan has been placed on top of the graduation video, with a direction in the upper right corner saying 'We are growing.' The London School of Economics, on the contrary, uses quite voluminous sentences describing the specifics of the university, made with a minimal minimalistic font, and time-lapse photography is replaced by static images lasting 2 seconds. 
It is important to consider the information features in each network:

University of Limerick delivers its news quite formally.lts photos are mostly amateur and simply takes with a mobile phone.

Oxford Brookes University posts questions to engage the audience.

Columbiaposts short call-to-action phrases.There is usually a lightweight text focused on informal communication. In addition, there is lots of humor and information that is not directly related to the University, but may be useful to students. Quite often,there are quotes from non-fiction books by teachers and former graduates. Teachers also give advice on how to solve a particular problem. Minimum textual information, i.e. interviews are only in the video format.

University of Phoenix achieves one of the most effective communications in terms of engaging the audience. The form of communication is a dialogue. The main task is motivation and stimulation for self-realizationand starting your own business, which is very important for distance learning. Students are usually asked questions about how they solve problems. Videos and photos are made in corporate colors; there is also quite a lot of text. Through all the posts, one idea is clearly traced that 'Phoenixes' are a single organism, all their achievements are joint, which in many respects should solve the problem of team absence in distance learning. There is lots of humor. GIF-exchange posts normally get a strong response. 'Phoenix' logos are presented in different versions, i.e. imitation of knitting, screensaver on a mobile, diary, etc. Photos and videos are mostly professional, but there are also some amateur one, taken by the students. Almost all the most effective SMM techniques are applied to engage the audience. Motivation is not always associated with education, for example, they simply offer to take off your 'happy' socks, while the post headband has just red socks showing the symbols of 'Phoenix'.

London School of Economics uses formal, business language. All information is presented in a unified style. First, a problem is indicated, and then information about the speaker is given. The language is quite dry, businesslike. Photo and 
video content made professionally. Posts on the upcoming speeches of experts hold a large share of the information from political scientists and economists at the University.

The university's social networks content naturally intersects, but each social network is directed in its own format.

General features of the universities social networks could be highlighted separately:

The YouTube channel publishes event videos, research results, videos on libraries, discussions on various topics, interviews with university professors, and social videos.

Playlists with successful university students.

The latest news from the university's student life, event announcements and interesting facts, scientific and social content, personal stories, achievements of university students, and entertaining content are present on Facebook (Boyd\&Ellison, 2008), (Zherebtsova et al, 2018).

The official Instagram accounts of universities have significantly reduced the information part. The photos are usually posted with very brief and concise comments. The most common topics are event photographs, university life photos, students' non-academic life shots, posters, historical black-andwhite photographs, posts involving interactive communication as well as communication with subscribers, and simply attractive images. (Yankovskaya et al, 2017).

\section{Discussion}

The study showed that the publics of the world's leading universities in social networks appeared at the time the network began to gain its popularity. The exception is the University of Limerick, which appeared in networks with a two-year delay.

The main platform for all universities is Facebook. The number of followers on Facebook exceeds up to twenty times the number of followers on Instagram. The number 
of followers on Instagram exceeds YouTube by almost three times; the exception is only the University of Phoenix, which has two times more subscribers on YouTube than on Instagram.

From the data obtained, it can be concluded that the number of subscribers does not directly depend on the number of publications. The University of Phoenix welcomes the smallest number of subscribers on Facebook, but it is 4.5 times more than The London School of Economics and Political Science, which comes right after The University of Phoenix.

It can be assumed that the number of subscribers to a university's social network depends on the number of students. The majority of universities have around fifteen thousand students, while the University of Phoenix hosts about 300 thousand students, i.e. almost thirty times more than the rest.

There is no a unified strategy for universities managing publicson social networks.

Each university has a varied posts frequency. However, it does not correlate with the level of audience involvement. For instance, the University of Phoenix was able to achieve the highest audience involvement, posting just once in two or three days.

Sunday is argued to bethe day when the audience is involved the most. However, there is no an exact time of day when the largest number of views is reached.

The ratio of educational, entertainment, branded and informational content is a real stumbling block for universities. The study shows that entertaining content, with a bit of humor, memes, parodies, gives high audience involvement, like Columbia University and University of Phoenix.However, this type of presentation can go against the educational organizationimage, as a respected 'temple of science'. For instance, Columbia has successfully dealt with this issue by getting the audience involved. At the same time, Oxford Brookes University and the London School of Economics adhere to a more formal material presentation. Thisissuerequiresfurtherdeeperresearch.

The optimal text and image ratio issue cannot be easily resolved, but no universities let their texts exceed the image size. Oxford Brookes University, Columbia and University of Phoenix think it is better to give a short text in which they can place a link to a site where a full article will be presented. University of Limerick andThe London School of Economics pay more attention to textual information, but there is not a single post that would be posted without an image.

Publics using a wide range of topics have a larger audience; they are more active and more involved, like Oxford Brookes University.

Page cover art should be regarded with great attention.Columbia University and London School of Economics run publics with dynamic covers and time-lapsed photography, 
which makes them even more attractive for the target audience.Well-embedded texts enhance the page impact.

The audience experience of the University of Phoenix shows that stimulation and motivation have a positive effect on audience involvement. Applying modern SMM trends attracts a large number of subscribers as well.

Social networks with a well-thought-out style concept attract more subscribers and are better perceived and remembered just like the University of Phoenix and The London School of Economics and Political Science.

\section{Conclusion}

The social networks structure analysis of leading universities with strong economic departments has revealed that universities really appreciate the role of social networks.

The main platform for international higher education institutions is Facebook; the representation on Instagram is actively developing as well, and third comes YouTube.

The number of publications does not affect the number of subscribers.

The number of university students directly relates with with the number of university public subscribers.

Nowadays, there is no single development strategy for managing the universities'social networks.

The high posts frequency does not lead to an increased number of subscribers and their involvement.

There is no single time when the universities audience is most active, but you can highlight the day of the week and it is Sunday.

The use of informal communication that encourages action, memes, humor, parodies significantly increases the audience and its involvement, but is not used by all universities, as can go against its image conception.

It is not yet possible to say that there is an ideal text and image ratio for university social networks publications, but the most common are one-third and two-thirds.

In the case, a large amount of text needs to be brought to the audience, the site links are used.

For a wider audience attraction, it is necessary to diversify publication topics.

Stimulating and motivating posts have a positive effect on the student audience.

The public covers design plays a role when you first visit the account. Dynamic 
videos made using time-lapse shooting look more dynamic and attract attention. Textual information embedded in these videos positively affects the public interest formation.

A single style solution for posts design massively simplifies the layout, and it improves the perception and page memorability.

In the future, a larger number of university networks should analyzed, specifically the question of humor, memes, parodies, and informal communication appropriateness.

\section{Bibliography}

Afonsky, S.A. (2017). The classification of archetypes and their influence on consumer decisions. Collection: XXX International Plekhanov readings. Collection of articles by graduate students and young scientists, 79-83. Retrieved from https:/ / elibrary.ru/item.asp?id=29651707

Baptista, J., Wilson, A., Galliers, R.D. \& Bynghall, S. (2017). Social media and the emergence of reflexiveness as a new capability for open strategy Long Range Plann. DOI: 10.1016/j.Irp.2016.07.005

Batura, T.V. (2013). Models and methods of computer social networks analysis. Software Products and Systems, (3), 24. Retrieved from https://elibrary.ru/item. asp? id $=21774135$

Bickel, P.J. \& Sarkar, P. (2016). Hypothesis testing for automated community detection in networks. J R Stat Soci Series B (Stat Methodol) 78(1), 253-273.

Boyd,D.\& EllisonN. B. (2008). SocialNetworkSites: Definition, History, andScholarship.Retrieved from https://www.danah.org/papers/JCMCIntro.pdf

Greenhow, C.\& Lewin, C. (2016). Social media and education: reconceptualizing the boundaries of formal and informal learning. Learning, Media and Technology (41),1, 6-30, D0I: 10.1080/17439884.2015.1064954.

Columbia University (2001-2018).Retrieved from https://www.columbia.edu/

Content for the university social networks. (2018). Study QA is a platform for finding higher education institutions abroad. https://studyqa.com/for-universities/ blog/content-for-social-media 
Engagementrate: how to calculate the coefficient of involvement in social networks (2018). (In Russ.). [Engagementrate: kak pravil'no schitat' koefficient vovlechennosti v social'nyh setyah. (2018).]. Retrieved from https://popsters. $\mathrm{ru} / \mathrm{blog} / \mathrm{post} / 55$

Érétéo, G., Gandon, F., Buffa, M.\& Corby, O. (2009).Analysis of a real online social network using semantic web frameworks. Proc. of the 8th Int. Semantic Web Conf.,1 80-195. Retrieved from https://scholar.google.com.tr/ citations? user=Ka3YgaAAAAJ \&hl=en

Freeman, L. C. (2004). The Development of Social Network Analysis: A Study in the Sociology of Science. Vancouver: Empirical Press.

Gradoselskaya, G. V. (2004). Network measurements in sociology: Textbook. Moscow: Phoenix. Retrieved from http://ecsocman.hse.ru/text/19188138

Gubina, 0. N. (2015). Modern low-cost Internet technologies for promoting educational services of universities.Service plus, 9 (1), 42-47. DOI: 10.12737/7581

Gureeva, A.N. (2015). Social networks asa media resource for image management of a Russian university. MediaScope, 1(3) Retrieved from https:// elibrary.ru/item. asp? id $=23182845$

Habibi, A., Mukinin, A., Riyanto, Y., Prasohjo, L. D., Sulistiyo, U., Sofwan, M., \& Saudagar, F. (2018). Building an Online Community: Student Teachers' Perceptions on the Advantages of Using Social Networking Services in a Teacher Education Program. Turkish Online Journal of Distance Education, 19(1), 46-61.

Huang, J., Baptista, J. \& Newell, S. (2015) Communication ambidexterity as a new capability to manage social media communication within organizations. J. Strateg. Inf. Syst. (24), 49-64.

Hudson, S., Roth, M., Madden, T. \& Hudson, R. (2015). The effects of social media on emotions, brand relationship quality, and word of mouth: An empirical study of music festival attendees. Tourism Management (47), 68-76.

Hutter, K., Nketia, B. A., Fuller, J. (2017) Falling short with participation - different effects of ideation, commenting, and evaluating behavior on open strategizing. Long Range Plann. (50), 335-370. 


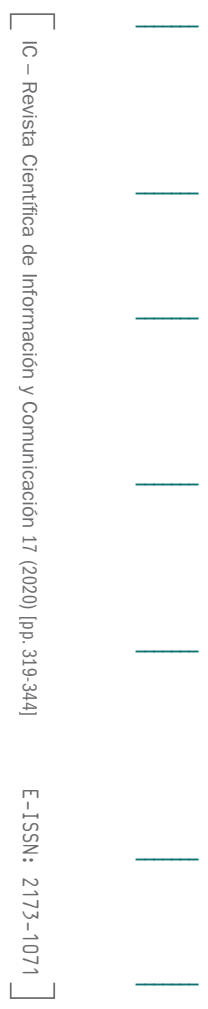

J. Benthaus, M.R. Risius, R. B. (2016).Social media management strategies for organizational impression management and their effect on public perception. The Journal of Strategic Information Systems (25), Is. 2, 127-139.

Karoui, M., Dudezert, A. \& Leidner, D. Strategies and symbolism in the adoption of organizational social networking systems.J. Strateg. Inf. Syst. (24), 14-32.

Makarets, A. B. (2009). Methodology for quality assessing of university websites marketing communications. Open Education, (4), 46-57. Retrieved from https:// elibrary.ru/item.asp? $\mathrm{id}=12828119$

Moreno, Y. L. (Ed. Zolotovitsky R. A.). (2001). Sociometry: An Experimental Method and the Science of Society. Moscow: Academic Project. Retrieved from https:// elibrary.ru/item.asp? id=22317842

Newman, M. E. J. (2016). Equivalence between modularity optimization and maximum likelihood methods for community detection. Phys. Rev., 94 (5): E 052315. doi:10.1103/PhysRevE.94.052315. Retrieved from http://link.aps.org/ doi/10.1103/PhysRevE.94.052315

Newman, M. \& Clauset, A. (2016). Structure and inference in annotated networks. Nature Communications, (7), Art. 11863.

Peel, L., Larremore D. B. \& Clauset, A. (2016). The ground truth about metadata and community detection in networks (15). Art 160805878. Retrieved from http:// arxiv.org/abs/1608.05878

QS Global World Ranking. (2018).QS Top Universities- world higher education platform. https://www.topuniversities.com

Rubin, Y. B. (2005). Entrepreneurial universities in innovative economy. Moscow: Market DS. https://spblib.ru/catalog/-/books/4686710-predprinimatel-skieuniversitety-v-innovacionnoj-ekonomike

Salnikov, V., Schaub, M.T. \& Lambiotte, R. (2016).Using higher-order Markov models to reveal flow-based communities in networks. Sci Rep (6), 23194. doi:10.1038/ srep23194. 
Samsonova, M. V.\& Samsonova, E. V. (2013). Marketing techniques that contribute to the development of the Russian market of educational services. Modern problems of science and education, (5) Retrieved from http://www.scienceeducation.ru/111-10105

Sekara, V., Stopczynski\& A. \& Lehmann, S. (2016). Fundamental structures of dynamic social networks. Proc Natl Acad Sci, 113 (36), 9977-9982. doi:10.1073/ pnas. 1602803113.

Shpolyanskaya, I. Y.\& Vorobieva, A. M. (2012). Models and methods for optimizing the structure of universities educational portals in the Internet marketing system. Bulletin of the Russian State University of Economics and Economics (Rostov State University of Economics), (37), 301-311. Retrieved from https://elibrary.ru/item. asp?id=17715412

Simmel, G. (1996). Selected works. Vol.2. Life contemplation. Moscow: Lawyer. Retrieved from http://www.al24.ru/wp-content/uploads/2013/05/\%D0\%B3\%D0\% B5\%D0\%BE_1.pdf

Tarasova, E. E.\& Shein, E. A. (2014).Improvement of methodical approaches to higher schools' marketing activity assessment on the basis of internet technologies application. Webology, 1 (11). Retrieved from http://www.webology.org/2014/ v11n1/a121.pdf

The official website of the University of Phoenix (2018). http://www.phoenix. eduRetrieved 21.12.18

Van Waes, S., De Maeyer, S., Moolenaar, N. M., Van Petegem, P., \& Van den Bossche, P. (2018). Strengthening networks: A social network intervention among higher education teachers. Learning and Instruction, 53, 34-49.

Wellman, B. \& Berkowitz, S.D. (1998). Social Structures: A Network Approach. Structural Analysis in the Social Sciences. Cambridge University Press. Retrieved from http://www.huffingtonpost.com/mark-drapeau/social-networks-forscientists_b_1282692.html

West, D.M. (2012). E-Government in the United States of America Brookings Institution - 2001-2019. https://www.brookings.edu/wp-content/uploads/2012/04/0826_ egovernment_west.pdf. 
White, H. C. (2008). Identity and Control. How Social Formations Emerge (2ed). Retrieved from https://press. princeton.edu/titles/8672.html.

Yang, J. \& Leskovec, J. (2015). Defining and evaluating network communities based on ground-truth. Knowl Inf Syst, 42(1): 181-213.

Yankovskaya, V. V., Petushkova, E. V. \& Ladogina, A. Yu. (2017). Education in Russia: from national model to the global one.Globalization and its SocioEconomic Consequences 17th International Scientific Conference Proceedings. 3013-3022Retrieved from https:// elibrary.ru/item.asp? id=32755641.

Zherebtsova, N. A., Afonsky, S. A. \& Kiselev, V. M. (2018). ZMET-analysis of archetypes among students.Bulletin of the Russian Economic University named after Plekhanov G.V., 6 (102), 82-102. Retrieved from https://elibrary.ru/item. asp?id=36565996. 